\title{
Thyrotropin-releasing Hormone Stimulation of Prolactin Release from Clonal Rat Pituitary Cells
}

\author{
EVIDENCE FOR ACTION INDEPENDENT OF EXTRACELLULAR CALCIUM
}

\author{
Marvin C. Gershengorn, Sylvia T. Hoffstein, Mario J. Rebecchi, \\ Elizabeth Geras, and Brian G. Rubin, Department of Medicine, New York \\ University Medical Center, New York, New York 10016
}

A B S T R A C T Thyrotropin-releasing hormone (TRH) stimulates prolactin release and ${ }^{45} \mathrm{Ca}^{2+}$ efflux from $\mathrm{GH}_{3}$ cells, a clonal strain of rat pituitary cells. Elevation of extracellular $\mathrm{K}^{+}$also induces prolactin release and increases ${ }^{45} \mathrm{Ca}^{2+}$ efflux from these cells. In this report, we distinguish between TRH and high $\mathrm{K}^{+}$as secretagogues and show that TRH-induced release of prolactin and ${ }^{45} \mathrm{Ca}^{2+}$ is independent of the extracellular $\mathrm{Ca}^{2+}$ concentration, but the effect of high $\mathrm{K}^{+}$on prolactin release and ${ }^{45} \mathrm{Ca}^{2+}$ efflux is dependent on the concentration of $\mathrm{Ca}^{2+}$ in the medium. The increment in ${ }^{45} \mathrm{Ca}^{2+}$ efflux induced by $50 \mathrm{mM} \mathrm{K} \mathrm{K}^{+}$during perifusion was reduced in a concentration-dependent manner by lowering extracellular $\mathrm{Ca}^{2+}$ from 1,500 to $0.02 \mu \mathrm{M}$ (by adding EGTA), whereas $1 \mu \mathrm{M}$ TRH enhanced ${ }^{45} \mathrm{Ca}^{2+}$ efflux similarly over the entire range of extracellular $\mathrm{Ca}^{2+}$ concentrations. Although $50 \mathrm{mM} \mathrm{K}{ }^{+}$caused release of $150 \mathrm{ng}$ prolactin from $40 \times 10^{6} \mathrm{GH}_{3}$ cells exposed to $1,500 \mu \mathrm{M} \mathrm{Ca}^{2+}$ (control), reduction of extracellular $\mathrm{Ca}^{2+}$ to $2.8 \mu \mathrm{M}$ decreased prolactin release caused by high $\mathrm{K}^{+}$to $<3 \%$ of controls and no prolactin release was detected after exposure to $50 \mathrm{mM}$ $\mathrm{K}^{+}$in medium with $0.02 \mu \mathrm{M}$ free $\mathrm{Ca}^{2+}$. In contrast, TRH caused release of $64 \mathrm{ng}$ of prolactin from $40 \times 10^{6} \mathrm{GH}_{3}$ cells exposed to medium with $1,500 \mu \mathrm{M} \mathrm{Ca}{ }^{2+}$, and release caused by TRH was still 50 and $35 \%$ of control in medium with 2.8 and $0.02 \mu \mathrm{M} \mathrm{Ca}^{2+}$, respectively. Furthermore, TRH transiently increased by 10 -fold the fractional efflux of ${ }^{45} \mathrm{Ca}^{2+}$ from $\mathrm{GH}_{3}$ cells in static incubations with 1,500 or $3.5 \mu \mathrm{M} \mathrm{Ca}^{2+}$, hereby confirming that the enhanced ${ }^{45} \mathrm{Ca}^{2+}$ efflux caused by TRH in both low and high $\mathrm{Ca}^{2+}$ medium was not an artifact of the perifusion system.

Data obtained with chlortetracycline (CTC), a probe of membrane-bound $\mathrm{Ca}^{2+}$, were concordant with those

Received for publication 1 December 1980 and in revised form 15 February 1981. obtained by measuring ${ }^{45} \mathrm{Ca}^{2+}$ efflux. Cellular fluorescence of CTC varied with the extracellular $\mathrm{Ca}^{2+}$ concentration and the duration of incubation. TRH decreased the fluorescence of cell-associated CTC in a manner strongly suggesting stimulus-induced mobilization of $\mathrm{Ca}^{2+}$, and this effect was still demonstrable in $\mathrm{GH}_{3}$ cells incubated in $50 \mathrm{mM} \mathrm{K}$.

These data suggest that TRH acts to mobilize sequestered cell-associated $\mathrm{Ca}^{2+}$ reflected as a ${ }^{45} \mathrm{Ca}^{2+}$ efflux which is independent of the extracellular $\mathrm{Ca}^{2+}$ concentration. Mobilization of sequestered $\mathrm{Ca}^{2+}$ into the cytoplasm may elevate free intracellular $\mathrm{Ca}^{2+}$ and serve to couple stimulation by TRH to secretion of prolactin.

\section{INTRODUCTION}

Thyrotropin-releasing hormone (TRH) ${ }^{1}$ stimulates release of thyrotropin and prolactin from pituitary cells (1), and these actions are dependent on $\mathrm{Ca}^{2+}(2,3)$. A role for $\mathrm{Ca}^{2+}$ in TRH stimulation of release of prolactin was shown directly in the study of Tashjian et al. (3), which showed that chelation of $\mathrm{Ca}^{2+}$ specifically inhibited TRH-stimulated prolactin release and that this inhibition was completely reversed by adding $\mathrm{Ca}^{2+}$. This finding for TRH action is consistent with the hypothesis (4) that $\mathrm{Ca}^{2+}$ is the coupling factor between stimulus and secretion. Indirect evidence in support of the contention that TRH may act by affecting cellular $\mathrm{Ca}^{2+}$ metabolism comes from studies demonstrating that TRH enhances ${ }^{45} \mathrm{Ca}^{2+}$ efflux both from rat anterior pituitary cells in vitro $(5,6)$ and from $\mathrm{GH}_{3}$ cells, a clonal strain of rat pituitary cells that produce prolactin $(7,8)$. The increase in the rate of ${ }^{45} \mathrm{Ca}^{2+}$ efflux caused by TRH may reflect an increase in the concentration of free cytosolic $\mathrm{Ca}^{2+}$; an increase which could

${ }^{1}$ Abbreviations used in this paper: BSS, balanced salt solution; CTC, chlortetracycline; TRH, thyrotropin-releasing hormone. 
be due to mobilization of $\mathrm{Ca}^{2+}$ from an intracellular pool (or pools), to enhanced entry of $\mathrm{Ca}^{2+}$ from the extracellular environment, or to both. A series of recent electrophysiological studies using $\mathrm{GH}_{3}$ cells (9-12) and primary mixed cultures of normal rat anterior pituitary cells (13) have demonstrated that TRH also causes an increase in the frequency of $\mathrm{Ca}^{2+}$-dependent action potentials, and it has been suggested that $\mathrm{Ca}^{2+}$ traversing the plasma membrane during action potentials may be involved in hormone secretion. In this regard, the action of TRH has been likened to that of depolarizing concentrations of $\mathrm{K}^{+}$which have been shown to release pituitary hormones by causing influx of extracellular $\mathrm{Ca}^{2+}(14)$.

In this report, we compare the effects of TRH and a depolarizing concentration of $\mathrm{K}^{+}(50 \mathrm{mM})$ on ${ }^{45} \mathrm{Ca}^{2+}$ efflux and prolactin release from $\mathrm{GH}_{3}$ cells and the effects of TRH and $50 \mathrm{mM} \mathrm{K}{ }^{+}$on the cellular fluorescence of chlortetracycline (CTC), a probe of membrane-bound $\mathrm{Ca}^{2+}(15,16)$. We demonstrate that stimulation of ${ }^{45} \mathrm{Ca}^{2+}$ efflux and prolactin release from $\mathrm{GH}_{3}$ cells caused by TRH, in contrast to that caused by depolarization by $\mathrm{K}^{+}$, is not dependent on the concentration of $\mathrm{Ca}^{2+}$ in the incubation medium, and we suggest that TRH mobilizes cell-associated $\mathrm{Ca}^{2+}$ in $\mathrm{GH}_{3}$ cells.

\section{METHODS}

Cell culture. $\mathrm{GH}_{3}$ cells (American Type Culture Collection, Rockville, Md.) were grown as monolayer cultures in Ham's F-10 medium supplemented with $15 \%$ horse serum and $2.5 \%$ fetal bovine serum at $37^{\circ} \mathrm{C}$ as described $(17,18)$. 3-5 $\mathrm{d}$ before an experiment, the cells were harvested with $0.02 \%$ EDTA and incubated in Eagle's Minimal Essential Medium (Grand Island Biological Co., Grand Island, N. Y.) for suspension culture supplemented with $15 \%$ horse and $2.5 \%$ fetal bovine sera (19). Cells were exposed to $0.02 \%$ EDTA for $10 \mathrm{~min}$ one additional time before incubation in this medium with ${ }^{45} \mathrm{Ca}^{2+}(2-8 \mu \mathrm{Ci} / \mathrm{ml})$ for $16-40 \mathrm{~h}$. Immediately before an experiment the cells were harvested by centrifugation at $180 \mathrm{~g}$ for $5 \mathrm{~min}$ and resuspended in a balanced salt solution (BSS) $-135 \mathrm{mM} \mathrm{NaCl}, 4.5 \mathrm{mM} \mathrm{KCl}$, $0.5 \mathrm{mM} \mathrm{MgCl}_{2}, 5.6 \mathrm{mM}$ glucose, $2 \mathrm{~g} /$ liter ovalbumin, and $10 \mathrm{mM}$ Hepes, $\mathrm{pH} 7.4-$ containing $1,500 \mu \mathrm{M}$ added $\mathrm{CaCl}_{2}$. The free $\mathrm{Ca}^{2+}$ concentration in $\mathrm{BSS}$ with no added $\mathrm{Ca}^{2+}$ was measured by colorimetric titration with arsenazo III dye (20); absorbance was measured at $650 \mathrm{~nm}$ in a double-beam spectrophotometer (Beckman Instruments, Inc., Palo Alto, Calif., model 25). The standard curve was constructed with EGTA/Ca EGTA buffer and $\left[\mathrm{Ca}^{2+}\right]$ free $\mathrm{w}^{*}$.. calculated using dissociation constant of $0.15 \mu \mathrm{M}$ for EGTA (21); reference cell contained BSS with $4 \mathrm{mM}$ EGTA. BSS was prepared fresh and its $\mathrm{Ca}^{2+}$ concentration measured before use. BSS contained $3.0 \pm 0.2 \mu \mathrm{M} \mathrm{Ca}^{2+}( \pm \mathrm{SEM})$.

Cell perifusion. The perifusion system is our modification (8) of the method described by Lowry and McMartin (22). In most experiments, $15 \times 10^{6}$ cells were stirred with $1 \mathrm{ml}$ settled resin (Bio-gel P-2, 200-400 mech, Bio-Rad Laboratories, Richmond, Calif.) and placed in a 3-ml disposable syringe on top of a nylon mesh $(20 \mu \mathrm{m}) .2 \mathrm{ml}$ of additional resin was placed on top of the cell column. In one experi- ment, large columns were prepared by stirring $40 \times 10^{6}$ cells with $3 \mathrm{ml}$ settled resin which was placed in a $10-\mathrm{ml}$ syringe with $2 \mathrm{ml}$ additional resin on top. Preparation of the cell column required $\sim 20 \mathrm{~min}$. The columns were perifused with BSS $\left(0.5-0.8 \mathrm{ml} / \mathrm{min}, 26^{\circ} \mathrm{C}\right)$ containing various concentrations of $\mathrm{Ca}^{2+}$, and the effluent was collected for 1-min intervals in a fraction collector. At the end of the experiment, cell viability as determined by exclusion of trypan blue was $>98$ and $95 \%$ for cells exposed to 1,500 and $2.8 \mu \mathrm{M} \mathrm{Ca}^{2+}$, respectively. $1 \mu \mathrm{M}$ TRH (Beckman Instruments, Inc.), $50 \mathrm{mM} \mathrm{K}^{+}$(prepared by substituting $\mathrm{KCl}$ for $\mathrm{NaCl}$ in BSS), or $20 \mu \mathrm{m} \mathrm{A23187} \mathrm{(Eli}$ Lilly \& Co., Indianapolis, Ind.) was added to the perifusate for $1 \mathrm{~min}$ at the indicated times. ${ }^{45} \mathrm{Ca}$ radioactivity was analyzed and prolactin was measured in perifusate. Radioimmunoassay of rat prolactin (18) was performed using reagents kindly supplied by Dr. A. F. Parlow and the Pituitary Hormone Distribution Program of the National Institute of Arthritis, Metabolism, and Digestive Diseases.

Static incubations. $\mathrm{GH}_{3}$ cells were preloaded with ${ }^{45} \mathrm{Ca}^{2+}$ $(4 \mu \mathrm{Ci} / \mathrm{ml})$ for $16 \mathrm{~h}$, as described above. The cells were washed twice with BSS with $1,500 \mu \mathrm{M} \mathrm{Ca}^{2+}$ and then preincubated with BSS with 1,500 or $3.2 \mu \mathrm{M} \mathrm{Ca}^{2+}$. After $20 \mathrm{~min}$, the cells were centrifuged at $180 \mathrm{~g}$ for $5 \mathrm{~min}$, resuspended in the same solutions $\left(1 \times 10^{6} / 0.1 \mathrm{ml}\right)$, and incubated at $26^{\circ} \mathrm{C}$ with constant stirring. After $5 \mathrm{~min}, 10 \mu \mathrm{l}$ of TRH in $0.9 \%$ $\mathrm{NaCl}$ was added. At the times indicated, the cells $(0.1 \mathrm{ml}$ of suspension) were separated by centrifugation at $8,000 \mathrm{~g}$ for $1 \mathrm{~min}$ through a layer of silicone in a microfuge $(23) \cdot{ }^{45} \mathrm{Ca}$ radioactivity in the supernate and in the cell pellet was measured. These data are expressed as the fractional efflux (rate constant) which is defined as the fraction of ${ }^{45} \mathrm{Ca}^{2+}$ leaving the cells per minute $(5,24)$.

CTC fluorescence measurements. Fluorescence measurements were made in a Spectrofluorometer Mark I (Farrand Optical Co., Valhalla, N. Y.) with excitation and emission wavelengths set usually at 400 and $515 \mathrm{~nm}$, respectively, with slit widths of $5 \mathrm{~nm}$. All measurements were made at $23^{\circ}$ $26^{\circ} \mathrm{C}$ with cells $\left(2-3 \times 10^{6} / \mathrm{ml}\right)$ suspended in BSS without ovalbumin or $\mathrm{Mg}^{2+}$, and with various concentrations of $\mathrm{Ca}^{2+}$ and CTC. For the uptake experiments, after a 20-30 min preincubation in BSS without ovalbumin or $\mathrm{Mg}^{2+}$ with the indicated $\left[\mathrm{Ca}^{2+}\right]$, the cell suspension was transferred to a cuvette, intrinsic fluorescence recorded, and $20 \mu \mathrm{l}$ of a concentrated solution of CTC was added (zero time). Fluorescence intensity was measured at the indicated times after the cuvette was inverted twice to resuspend settled cells; intrinsic fluorescence which was $<5 \%$ of the total was subtracted. For experiments in which effects of TRH and $\mathrm{K}^{+}$were measured, cells were loaded with CTC for the indicated times, centrifuged at $800 \mathrm{~g}$ for $2 \mathrm{~min}$, and resuspended in $2 \mathrm{ml}$ of fresh BSS without ovalbumin or $\mathrm{Mg}^{2+}$ containing the indicated $\left[\mathrm{Ca}^{2+}\right]$ and no CTC. The fluorescence intensity decreased in a biphasic fashion: an initial rapid loss of fluorescence which lasted $<2 \mathrm{~min}$ followed by a slower sustained loss. The effects of TRH and $50 \mathrm{mM} \mathrm{K}{ }^{+}$were studied during the second phase of fluorescence loss by means of dilution of the cell suspension with $1 \mathrm{ml}$ of BSS without ovalbumin or $\mathrm{Mg}^{2+}$ (control), or with $1 \mathrm{ml}$ of a solution in which $\mathrm{NaCl}$ was replaced by $\mathrm{KCl}$. After an additional $3 \mathrm{~min}, 20 \mu \mathrm{l}$ of a concentrated solution of TRH (the final concentration was $1 \mu \mathrm{M}$ ) or of $0.9 \%$ $\mathrm{NaCl}$ (control) was added, the cuvette was inverted twice, and the fluorescence loss was monitored.

\section{RESULTS}

${ }^{45} \mathrm{Ca}^{2+}$ efflux studies. Previous studies (8) using this perifusion system have shown that TRH and $50 \mathrm{mM} \mathrm{K}^{+}$ 


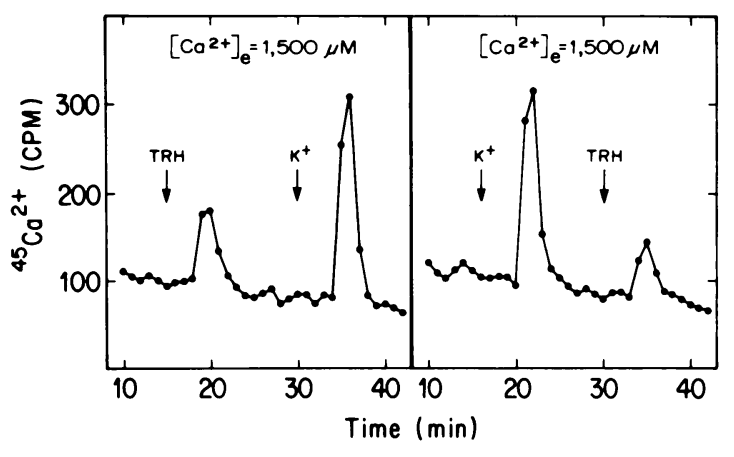

FIGURE 1 Effect of TRH and a depolarizing concentration of $\mathrm{K}^{+}$on ${ }^{45} \mathrm{Ca}^{2+}$ efflux. $\mathrm{GH}_{3}$ cells, preincubated with ${ }^{45} \mathrm{Ca}^{2+}(2$ $\mu \mathrm{Ci} / \mathrm{ml}$ ) for $16 \mathrm{~h}$, were perifused with BSS containing 1,500 $\mu \mathrm{M} \mathrm{Ca}^{2+}\left(0.5 \mathrm{ml} / \mathrm{min}, 26^{\circ} \mathrm{C}\right)$ and $1 \mu \mathrm{M} \mathrm{TRH}$ or $50 \mathrm{mM} \mathrm{K}^{+}$was added to the perifusate for $1 \mathrm{~min}$ beginning at 15 or $30 \mathrm{~min}$.

transiently enhanced the rate of ${ }^{45} \mathrm{Ca}^{2+}$ efflux from $\mathrm{GH}_{3}$ cells in the presence of $\mathrm{Ca}^{2+}$ in the medium. Comparisons of the effects of these two secretagogues applied sequentially to $\mathrm{GH}_{3}$ cells showed that the degree of enhancement was specific to each stimulus and was not affected by the sequence in which the stimuli were applied (Fig. 1). In the presence of 1,500 $\mu \mathrm{M} \mathrm{Ca}^{2+}$, the efflux induced by TRH was not as great as the efflux induced by $50 \mathrm{mM} \mathrm{K} \mathrm{K}^{+}$whether it was applied to the cells before or after the $\mathrm{K}^{+}$. The apparent lag period between addition of $\mathrm{TRH}$ or $\mathrm{K}^{+}$to the perifusate and the increase in ${ }^{45} \mathrm{Ca}^{2+}$ efflux and the difference in duration of this period for TRH and $\mathrm{K}^{+}$ is completely accounted for by the delay intrinsic to the perifusion system (8).

Exposure of $\mathrm{GH}_{3}$ cells to various $\left[\mathrm{Ca}^{2+}\right]_{e}$ had different effects on stimulus-enhanced ${ }^{45} \mathrm{Ca}^{2+}$ efflux, depending on whether the stimulus was TRH or $50 \mathrm{mM}$ $\mathrm{K}^{+}$(Fig. 2). There was no measurable effect of $\left[\mathrm{Ca}^{2+}\right]_{\mathrm{e}}$ on the enhanced ${ }^{45} \mathrm{Ca}^{2+}$ efflux caused by TRH. In contrast, decreasing $\left[\mathrm{Ca}^{2+}\right]_{e}$ from 100 to $3.8 \mu \mathrm{M}$ caused a dose-dependent decrease in the effect of 50 $\mathrm{mM} \mathrm{K}{ }^{+}$on ${ }^{45} \mathrm{Ca}^{2+}$ efflux. Depolarization of $\mathrm{GH}_{3}$ cells by $50 \mathrm{mM} \mathrm{K}^{+}(8)$ was not affected by varying $\left[\mathrm{Ca}^{2+}\right]_{\mathrm{e}}$ (unpublished observations). These data are consistent with the hypothesis that $50 \mathrm{mM} \mathrm{K}{ }^{+}$increased plasma membrane permeability to $\mathrm{Ca}^{2+}$, which resulted in influx of $\mathrm{Ca}^{2+}$ when $\left[\mathrm{Ca}^{2+}\right]_{e}$ markedly exceeded that in the cytosol. The influx of $\mathrm{Ca}^{2+}$ may have elevated the free cytosolic $\mathrm{Ca}^{2+}$ and then was reflected as an increased efflux of ${ }^{45} \mathrm{Ca}^{2+}$ as the cellular response to lower free $\mathrm{Ca}^{2+}$ was accomplished, in part, by extruding $\mathrm{Ca}^{2+}$. An alternate explanation, that $\mathrm{K}^{+}$depolarization increases $\mathrm{Ca}^{2+}-\mathrm{Ca}^{2+}$ exchange without affecting free cytosolic $\left[\mathrm{Ca}^{2+}\right]$ appears less likely since $\mathrm{K}^{+}$depolarization appears to increase $\mathrm{Ca}^{2+}$ uptake by many secretory cells (25). In any event, TRH did not appear to act by causing an influx of $\mathrm{Ca}^{2+}$ from the medium since

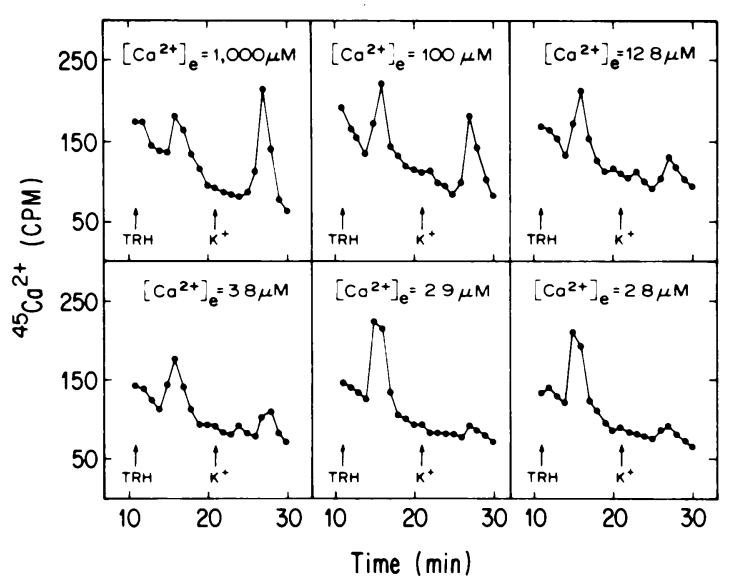

Figure 2 Effect of $\left[\mathrm{Ca}^{2+}\right]_{\mathrm{e}}$ on enhancement of ${ }^{45} \mathrm{Ca}^{2+}$ efflux by $\mathrm{TRH}$ and $50 \mathrm{mM} \mathrm{K}^{+}$. $\mathrm{GH}_{3}$ cells, preincubated with ${ }^{45} \mathrm{Ca}^{2+}(2$ $\mu \mathrm{Ci} / \mathrm{ml}$ ) for $16 \mathrm{~h}$, were perifused with $\mathrm{BSS}$ containing the indicated concentrations of $\mathrm{Ca}^{2+}\left(0.5 \mathrm{ml} / \mathrm{min}, 26^{\circ} \mathrm{C}\right)$ beginning at time 0 . TRH $(1 \mu \mathrm{M})$ and $50 \mathrm{mM} \mathrm{K} \mathrm{K}^{+}$were present in the perifusate for $1 \mathrm{~min}$ beginning at 11 and $21 \mathrm{~min}$, respectively. These results are representative of one of two similar experiments.

its effect on ${ }^{45} \mathrm{Ca}^{2+}$ efflux was not dependent on extracellular $\mathrm{Ca}^{2+}$.

The extracellular $\mathrm{Ca}^{2+}$ requirement for $\mathrm{K}^{+}$-induced ${ }^{45} \mathrm{Ca}^{2+}$ efflux was paralled by a similar requirement for $\mathrm{K}^{+}$stimulation of prolactin release. Likewise, the lack of dependence of TRH-induced ${ }^{45} \mathrm{Ca}^{2+}$ efflux on $\mathrm{Ca}^{2+}$ in the medium was paralleled by a similar independence of TRH-induced prolactin release from extracellular $\mathrm{Ca}^{2+}$ (Fig. 3). Hence, TRH stimulated release of prolactin from cells perifused with medium with either 1,500 or $3.5 \mu \mathrm{M} \mathrm{Ca}^{2+}$. In contrast, in this experiment, $50 \mathrm{mM} \mathrm{K} \mathrm{K}^{+}$enhanced prolactin release to a much greater extent than TRH in medium with $1,500 \mu \mathrm{m} \mathrm{Ca}{ }^{2+}$, whereas no stimulation of prolactin release by $50 \mathrm{mM}$ $\mathrm{K}^{+}$was detected in medium with $3.5 \mu \mathrm{M} \mathrm{Ca}{ }^{2+}$. The inability of $\mathrm{K}^{+}$depolarization to enhance ${ }^{45} \mathrm{Ca}^{2+}$ efflux in low $\mathrm{Ca}^{2+}$ medium was not due to depletion of cell-associated ${ }^{45} \mathrm{Ca}^{2+}$ radioactivity because the calcium ionophore, A23187, caused similar increments in ${ }^{45} \mathrm{Ca}^{2+}$ efflux from cells exposed to either 1,500 or $3.5 \mu \mathrm{M}$ $\mathrm{Ca}^{2+}$ (Fig. 3).

In an attempt to quantify the effect of extracellular $\mathrm{Ca}^{2+}$ in stimulation of prolactin release from $\mathrm{GH}_{3}$ cells by TRH and $50 \mathrm{mM} \mathrm{K}$, a perifusion column with $40 \times 10^{6}$ cells was employed. The effects of TRH and $50 \mathrm{mM} \mathrm{K}^{+}$on prolactin release were compared in perifusion medium containing 1,500 and $2.8 \mu \mathrm{M} \mathrm{Ca}^{2+}$ and in medium in which the concentration of unbound or free $\mathrm{Ca}^{2+}$ was lowered to $0.02 \mu \mathrm{M}$ by adding $33 \mu \mathrm{M}$ EGTA to BSS (Fig. 4). Between 10 and 15 min after beginning perifusion with medium containing $2.8 \mu \mathrm{M}$ $\mathrm{Ca}^{2+}$ or $0.02 \mu \mathrm{M}$ free $\mathrm{Ca}^{2+}$ there was a transient, but 


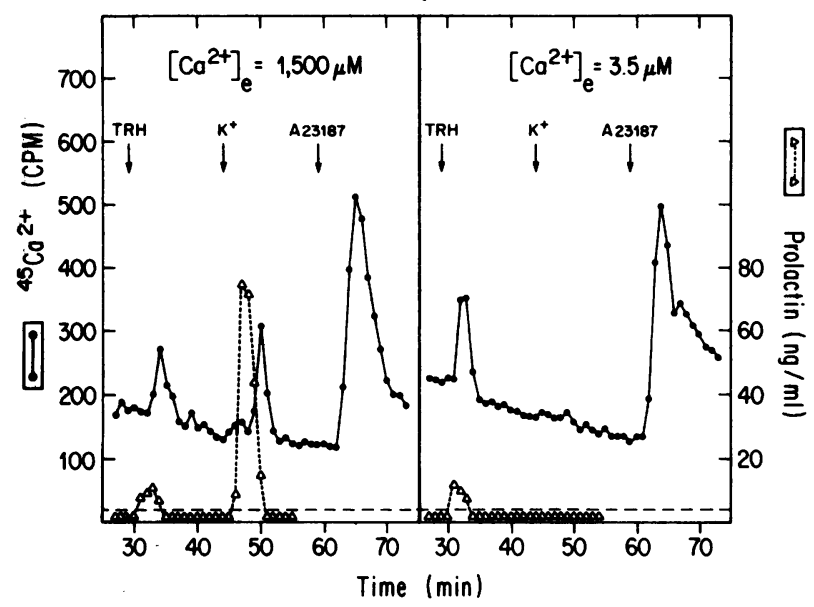

FIGURE 3 Comparison of the effects of TRH, $50 \mathrm{mM} \mathrm{K}^{+}$, and A23187 on ${ }^{45} \mathrm{Ca}^{2+}$ efflux and TRH and $50 \mathrm{mM} \mathrm{K}{ }^{+}$on prolactin release in medium with 1,500 and $3.5 \mu \mathrm{M} \mathrm{Ca}^{2+}$. $\mathrm{GH}_{3}$ cells used for perifusion in the presence of $1,500 \mu \mathrm{M} \mathrm{Ca}{ }^{2+}$ (left-hand panel) were preincubated with $2 \mu \mathrm{Ci} / \mathrm{ml}^{45} \mathrm{Ca}^{2+}$ for $16 \mathrm{~h}$, and the cells used for perifusion without added $\mathrm{Ca}^{2+}$ (right-hand panel) were preincubated with $8 \mu \mathrm{Ci} / \mathrm{ml}^{45} \mathrm{Ca}^{2+}$ for $16 \mathrm{~h}$. Rate of perifusion was $0.6 \mathrm{ml} / \mathrm{min}$ at $26^{\circ} \mathrm{C}$. TRH $(1 \mu \mathrm{M}), 50 \mathrm{mM} \mathrm{K} \mathrm{K}^{+}$, or A23187 $20 \mu \mathrm{M}$ was present in the perifusate for $1 \mathrm{~min}$ beginning at 29,44 , and $59 \mathrm{~min}$, respectively. The dashed lines at the lower part of both panels represent the limit of detectability of the prolactin immunoassay. These results are representative of one of three similar experiments.

very marked, efflux of ${ }^{45} \mathrm{Ca}^{2+}$ from $\mathrm{GH}_{3}$ cells (data not shown). In this experiment the increment in prolactin release elicited by $50 \mathrm{mM} \mathrm{K}^{+}$in medium with $2.8 \mu \mathrm{M}$ $\mathrm{Ca}^{2+}$ was $<3 \%$ of that in medium with $1,500 \mu \mathrm{M} \mathrm{Ca}^{2+}$ which was $150 \mathrm{ng}$ prolactin released; there was no de-

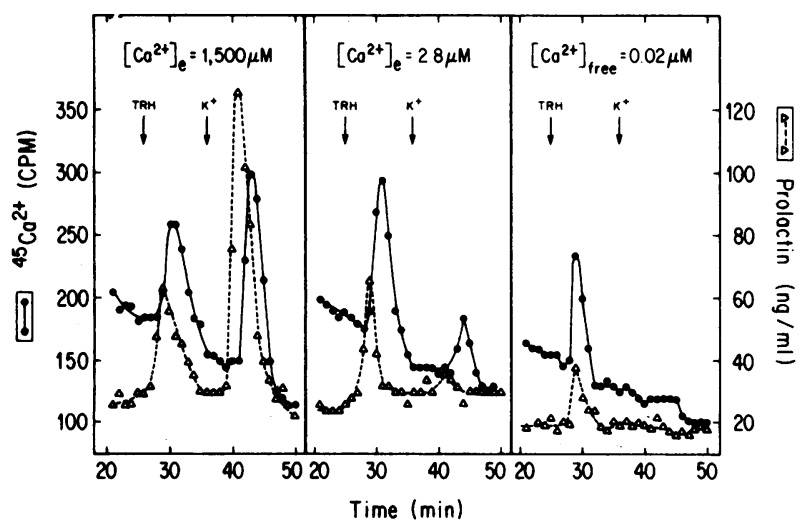

FIgURE 4 Comparison of the effects of TRH and $50 \mathrm{mM} \mathrm{K}$ on ${ }^{45} \mathrm{Ca}^{2+}$ efflux and prolactin release in medium with 1,500 and $2.8 \mu \mathrm{M} \mathrm{Ca}^{2+}$ and $0.02 \mu \mathrm{M}$ free $\mathrm{Ca}^{2+} . \mathrm{GH}_{3}$ cells $\left(40 \times 10^{6} /\right.$ column) were preincubated with ${ }^{45} \mathrm{Ca}^{2+}(2 \mu \mathrm{Ci} / \mathrm{ml})$ for $16 \mathrm{~h}$. Rate of perifusion was $0.8 \mathrm{ml} / \mathrm{min}$ at $26^{\circ} \mathrm{C}$. TRH $(1 \mu \mathrm{M})$ and 50 $\mathrm{mM} \mathrm{K}^{+}$were present in the perifusate for $1 \mathrm{~min}$ beginning at 25 and $36 \mathrm{~min}$, respectively. Medium containing $0.02 \mu \mathrm{M}$ unbound or free $\mathrm{Ca}^{2+}\left(\left[\mathrm{Ca}^{2+}\right]_{\text {free }}\right)$ was prepared by adding 33 $\mu M$ EGTA to BSS. tectable increment in medium with $0.02 \mu \mathrm{M}$ free $\mathrm{Ca}^{2+}$. In contrast, TRH enhanced prolactin release under all conditions; prolactin release stimulated by TRH was 50 and $35 \%$ of control of $64 \mathrm{ng}$ (BSS with 1,500 $\mu \mathrm{M}$ $\left.\mathrm{Ca}^{2+}\right)$ in medium with $2.8 \mu \mathrm{M} \mathrm{Ca}{ }^{2+}$ and $0.02 \mu \mathrm{M}$ free $\mathrm{Ca}^{2+}$, respectively. These differences for TRH, however, may be due to loss of $\mathrm{Ca}^{2+}$ from a critical cell-associated pool (or pools) and not to changes in $\mathrm{Ca}^{2+}$ in the medium, because there was a marked efflux of ${ }^{45} \mathrm{Ca}^{2+}$ from cells before the addition of secretagogues. Hence, extracellular $\mathrm{Ca}^{2+}$ was necessary for $\mathrm{K}^{+}$-stimulated, but not for TRH-stimulated prolactin release.

To confirm that the TRH-induced increase in ${ }^{45} \mathrm{Ca}^{2+}$ efflux from $\mathrm{GH}_{3}$ cells was independent of $\left[\mathrm{Ca}^{2+}\right]_{e}$ and that no artifact was introduced by the perifusion system, ${ }^{45} \mathrm{Ca}^{2+}$ efflux was measured from $\mathrm{GH}_{3}$ cells in static incubations. Fig. 5 illustrates similar effects of TRH on the fractional efflux of ${ }^{45} \mathrm{Ca}^{2+}$ from cells incubated in medium with 1,500 or $3.5 \mu \mathrm{M} \mathrm{Ca}^{2+}$. Basal fractional efflux from cells incubated with $3.5 \mu \mathrm{M}$ $\mathrm{Ca}^{2+}\left(0.027 \pm 0.003 \mathrm{~min}^{-1}\right)( \pm \mathrm{SEM})$ was more than twice that of cells incubated with $1,500 \mu \mathrm{M} \mathrm{Ca}{ }^{2+}$ $\left(0.011 \pm 0.002 \mathrm{~min}^{-1}\right)(P<0.01)$. In both instances, TRH caused a transient increase of $\sim 10$-fold in the fractional efflux of ${ }^{45} \mathrm{Ca}^{2+}$ which returned to basal levels within 4 min even though TRH was present continuously.

CTC fluorescence studies. The fluorescence emission spectrum obtained after incubating $\mathrm{GH}_{3}$ cells with $100 \mu \mathrm{M}$ CTC for $10 \mathrm{~min}$ was compared to emission

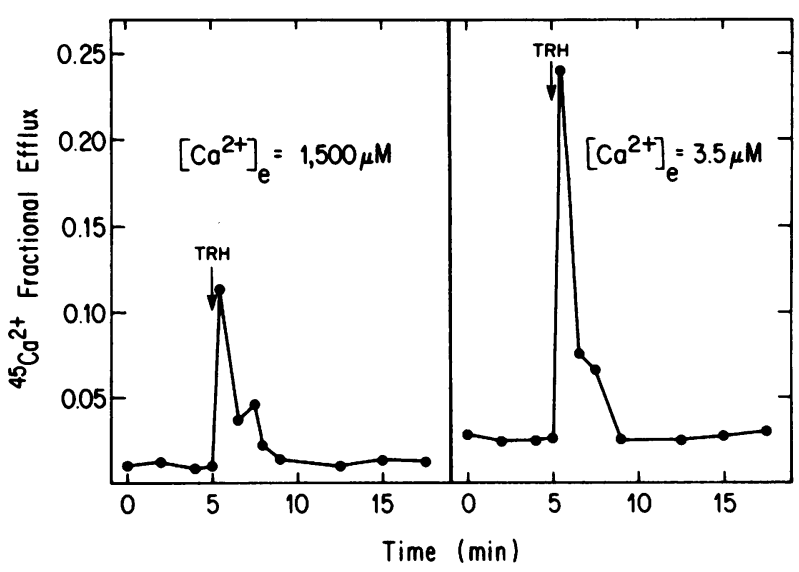

Figure 5 Effect of TRH on the ${ }^{45} \mathrm{Ca}^{2+}$ fractional efflux in the presence of 1,500 and $3.5 \mu \mathrm{M} \mathrm{Ca}{ }^{2+}$ during static incubations. $\mathrm{GH}_{3}$ cells, preloaded with ${ }^{45} \mathrm{Ca}^{2+}(4 \mu \mathrm{Ci} / \mathrm{ml})$ for $16 \mathrm{~h}$, were preincubated with constant stirring with BSS containing 1,500 or $3.5 \mu \mathrm{M} \mathrm{Ca}^{2+}$. After $20 \mathrm{~min}$ the cells were washed and resuspended in fresh solutions (time 0 ). Cells incubated in BSS with $3.5 \mu \mathrm{M} \mathrm{Ca}{ }^{2+}$ contained $43 \%$ of ${ }^{45} \mathrm{Ca}^{2+}$ of cells incubated with BSS containing $1,500 \mu \mathrm{M} \mathrm{Ca}{ }^{2+}$. TRH was added at the time indicated. The points represent the mean of duplicate determinations. These results are representative of one of two similar experiments. 
spectra of the $\mathrm{Ca}^{2+}$ - and $\mathrm{Mg}^{2+}$-chelates of CTC in $90 \%$ methanol/10\% BSS without ovalbumin, an amphipathic solvent in which the $\mathrm{Ca}^{2+}$ and $\mathrm{Mg}^{2+}$ complexes of CTC have spectra similar to those in membranes $(15,16)$. The emission maximum and shape of the emission spectrum of CTC-loaded $\mathrm{GH}_{3}$ cells (data not shown) indicated that $\mathrm{CTC}$ in $\mathrm{GH}_{3}$ cells was complexed with $\mathrm{Ca}^{2+}$ and $\mathrm{Mg}^{2+}$. The effect of increasing $\left[\mathrm{Ca}^{2+}\right]_{e}$ on the fluorescence associated with $\mathrm{GH}_{3}$ cells after $10 \mathrm{~min}$ of incubation with $100 \mu \mathrm{M}$ CTC is illustrated in Fig. 6. There was a concentration-dependent increase in fluorescence intensity between $\left[\mathrm{Ca}^{2+}\right]_{\mathrm{e}}$ of $100 \mu \mathrm{M}$ and $10,000 \mu \mathrm{M}$. This suggests that there is a pool (or pools) of $\mathrm{Ca}^{2+}$ within these cells which can be altered by variations in the $\left[\mathrm{Ca}^{2+}\right]_{e}$ and which can be probed by CTC. Since it has been shown that the enhanced fluorescence of CTC in biological specimens is due to its interaction with divalent cations in the lipid or hydrophobic domain of membranes, it was likely that this pool of $\mathrm{Ca}^{2+}$ was present within membranes of $\mathrm{GH}_{3}$ cells.

To gain further insight into the pool of $\mathrm{Ca}^{2+}$ probed by CTC in $\mathrm{GH}_{3}$ cells, we determined the time-course of uptake of CTC. Fig. 7 illustrates the change with time of fluorescence associated with $\mathrm{GH}_{3}$ cells exposed to different concentrations of CTC in the presence of 100 and $3.5 \mu \mathrm{M} \mathrm{Ca}^{2+}$. The intensity of fluorescence was dependent on the $\left[\mathrm{Ca}^{2+}\right]_{e}$ (see above), the concentration of CTC, and the duration of exposure to CTC. For example, the fluorescence intensity at $10 \mathrm{~min}$ was only $40 \%$ of the intensity at $60 \mathrm{~min}$ in cells exposed to $100 \mu \mathrm{M} \mathrm{CTC}$ and $\left[\mathrm{Ca}^{2+}\right]_{\mathrm{e}}$ of 100 or $3.5 \mu \mathrm{M}$. This may have been due to increased labeling by CTC of the same $\mathrm{Ca}^{2+}$ pool (or pools) or to labeling of different pools with increasing duration of exposure.

The effects of TRH and a depolarizing concentration of $\mathrm{K}^{+}$on CTC fluorescence associated with $\mathrm{GH}_{3}$ cells

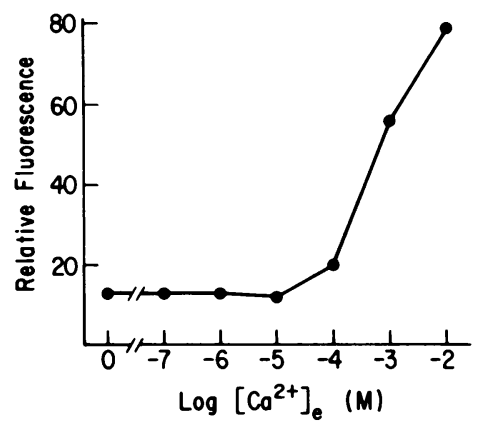

Figure 6 Dose-response effect of increasing $\left[\mathrm{Ca}^{2+}\right]_{e}$ on the fluorescence of CTC associated with $\mathrm{GH}_{3}$ cells. $\mathrm{GH}_{3}$ cells $\left(2 \times 10^{6} / \mathrm{ml}\right)$ were incubated in BSS without ovalbumin or $\mathrm{Mg}^{2+}$ containing the indicated concentrations of $\mathrm{Ca}^{2+}$ for 20 min and then $100 \mu \mathrm{M}$ CTC was added. After $10 \mathrm{~min}$ the cuvette was inverted twice and the fluorescence intensity measured. Intrinsic fluorescence was subtracted from each value.

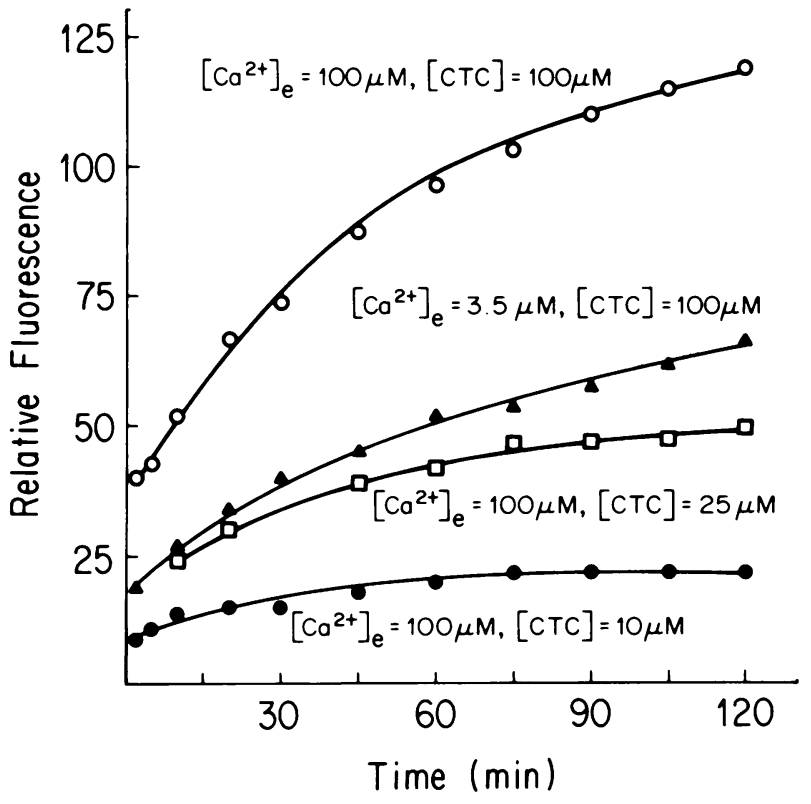

FIgURE 7 Time-course of the uptake of CTC into $\mathrm{GH}_{3}$ cells. $\mathrm{GH}_{3}$ cells $\left(3 \times 10^{6} / \mathrm{ml}\right)$ were incubated in BSS without ovalbumin or $\mathrm{Mg}^{2+}$ with 100 or $3.5 \mu \mathrm{M} \mathrm{Ca}^{2+}$. After $30 \mathrm{~min}$ (time $0)$, CTC in the indicated concentration was added and the fluorescence intensity measured at the times indicated. Intrinsic fluorescence was subtracted from each value.

were studied. For these experiments cells were exposed to CTC, centrifuged, and resuspended in fresh solutions without CTC. Fig. 8 illustrates the changes in fluorescence intensity of $\mathrm{GH}_{3}$ cells exposed to 100 $\mu \mathrm{M}$ CTC for $10 \mathrm{~min}$ (uptake) and then, after removing CTC from the medium, to $50 \mathrm{mM} \mathrm{K}^{+}$(after $3 \mathrm{~min}$ ), and to $1 \mu \mathrm{M}$ TRH (after $6 \mathrm{~min}$ ). $\mathrm{K}^{+}$depolarization caused a small increase in the rate of fluorescence loss which was shown in other experiments to persist for at least $10 \mathrm{~min}$. TRH also increased the rate of fluorescence loss but this differed from that induced by $50 \mathrm{mM} \mathrm{K}$ in two important ways. First, the effect of TRH was transient, lasting $<1.5 \mathrm{~min}$; that is, the rate of loss of fluorescence before TRH addition was reached again within $1.5 \mathrm{~min}$ after exposure. Second, the magnitude of the decrease in fluorescence achieved within the first 0.5 min after addition of TRH was much greater than after exposure to $50 \mathrm{mM} \mathrm{K}^{+}$. The transient enhancement of fluorescence loss induced by TRH suggests that TRH displaces abruptly a portion of the membrane-bound $\mathrm{Ca}^{2+}$ monitored by CTC.

Further evidence supporting the contention that TRH mobilizes $\mathrm{Ca}^{2+}$ from a cellular membraneassociated pool, and not via influx of $\mathrm{Ca}^{2+}$ from the medium, may be derived from the observation that the effect of TRH on CTC fluorescence was observed even in $\mathrm{GH}_{3}$ cells that had been exposed 3 min earlier to a depolarizing concentration of $\mathrm{K}^{+}$(Fig. 8, lowest tracing in each panel). 


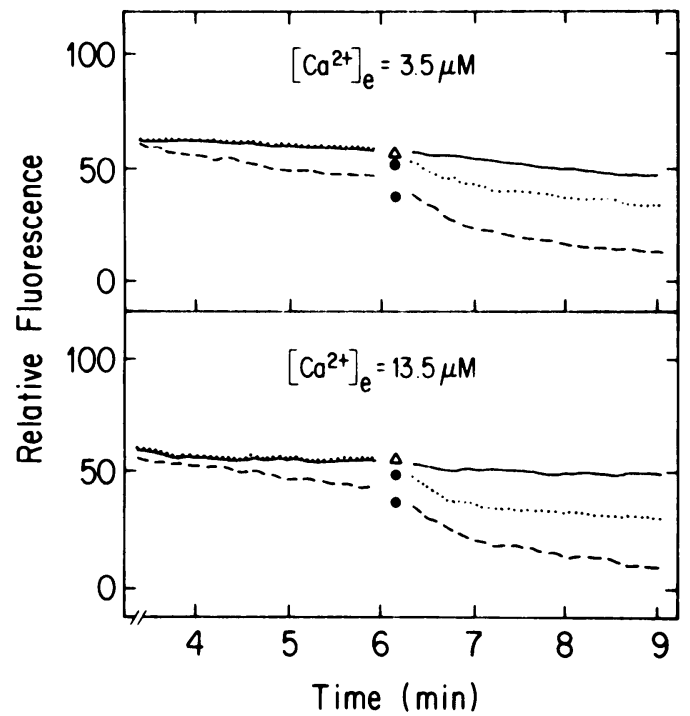

FigURF 8 Effect of TRH and $50 \mathrm{mM} \mathrm{K}^{+}$on CTC Huorescence associated with $\mathrm{GH}_{3}$ cells. $\mathrm{GH}_{3}$ cells $\left(2 \times 10^{6} / \mathrm{ml}\right)$ were incubated in BSS without ovalbumin with 13 or $3.5 \mu \mathrm{M} \mathrm{Ca}^{2+}$. After $30 \mathrm{~min}, 100 \mu \mathrm{M}$ CTC was added. After $10 \mathrm{~min}$ of uptake, the cells were centrifuged, divided into three portions and resuspended in $2 \mathrm{ml}$ of fresh solution without (CTC. After $3 \mathrm{~min}$ of incubation without CTC, $1 \mathrm{ml}$ of BSS without ovalbumin or $\mathrm{Mg}^{2+}$ was added to two cuvettes (solid and dotted lines) and 1 $\mathrm{ml}$ of $150 \mathrm{mM} \mathrm{KCl}$ was added to the last cuvette $(50 \mathrm{mM} \mathrm{K}$ final concentration, dashed line). After $6 \mathrm{~min}, 30 \mu \mathrm{l}$ of TRH (final concentration $1 \mu \mathrm{M}, 0$ ) or $0.9 \% \mathrm{NaCl}(\triangle$, control) was added where indicated. The break in the tracing indicates where the light source was turned off and the factor added. Each tracing is representative of four similar experiments.

TRH appeared to mobilize $\mathrm{Ca}^{2+}$ only from a pool (or pools) that was monitored completely by incubating $\mathrm{GH}_{3}$ cells with $100 \mu \mathrm{M}$ CTC for $10 \mathrm{~min}$. This conclusion was based on the finding that TRH caused a similar absolute decrease in CTC fluorescence irrespective of the duration of incubation with CTC between 10 and $120 \mathrm{~min}$, even though the total fluorescence intensity increased with longer incubations (data not shown). Hence, it seems likely that TRH mobilized $\mathrm{Ca}^{2+}$ specifically from a cell-associated pool (or pools) that is readily probed by CTC.

\section{DISCUSSION}

These data demonstrate that TRH stimulation of prolactin release and ${ }^{45} \mathrm{Ca}^{2+}$ efflux from $\mathrm{GH}_{3}$ cells was not dependent on the concentration of $\mathrm{Ca}^{2+}$ in the incubation medium and suggest that TRH mobilizes $\mathrm{Ca}^{2+}$ from a cell-associated pool. TRH increased ${ }^{45} \mathrm{Ca}^{2+}$ efflux from cells studied in a perifusion system and in static incubations even when there was only $0.02 \mu \mathrm{M}$ free $\mathrm{Ca}^{2+}$ in the medium. In the perifusion system, TRH increased prolactin release at all $\left[\mathrm{Ca}^{2+}\right]_{e}$. These findings for TRH were in marked contrast to those observed when $\mathrm{GH}_{3}$ cells were exposed to a depolarizing concentration of $\mathrm{K}^{+}(50 \mathrm{mM})$ since the $\mathrm{K}^{+}$-induced increase in ${ }^{45} \mathrm{Ca}^{2+}$ efflux and prolactin release were both dependent on $\left[\mathrm{Ca}^{2+}\right]_{e}$. Additional evidence supporting the contention that TRH and $\mathrm{K}^{+}$depolarization affected cellular $\mathrm{Ca}^{2+}$ metabolism differently was obtained from studies of $\mathrm{GH}_{3}$ cells incubated with CTC, a fluorescent probe of membrane-bound $\mathrm{Ca}^{2+}(15,16)$. During incubation of cells preloaded with CTC, TRH caused an abrupt, marked, but transient increase in fluorescence loss. The limited nature of the fluorescence loss, even in the continued presence of TRH, paralleled the transient increase in ${ }^{45} \mathrm{Ca}^{2+}$ efflux induced by TRH. In contrast, $\mathrm{K}^{+}$depolarization caused only a small and persistent increase in the rate of CTC fluorescence loss. These observations confirm our previous suggestion, based on findings that TRH did not depolarize $\mathrm{GH}_{3}$ cells (8), and those of Milligan and Kraicer (26) and Eto et al. (27), that the mechanisms by which TRH and a depolarizing concentration of $\mathrm{K}^{+}$ may lead to prolactin release are clearly different.

In this study, CTC, which has been used successfully to monitor changes in membrane-associated $\mathrm{Ca}^{2+}$ in isolated mitochondria $(28,29)$, sarcoplasmic reticulum vesicles (30), and intact cells (30-34), was employed to complement the ${ }^{45} \mathrm{Ca}^{2+}$ efflux studies to determine indirectly whether TRH mobilized $\mathrm{Ca}^{2+}$ from a cellular membrane-associated pool (or pools). This was important since the enhanced ${ }^{45} \mathrm{Ca}^{2+}$ efflux caused by TRH could have been due simply to release of ${ }^{45} \mathrm{Ca}^{2+}$ from secretory granules during the exocytotic process. Although other factors could have affected CTC fluorescence, the very close parallels between the effects of TRH on ${ }^{45} \mathrm{Ca}^{2+}$ efflux and CTC fluorescence suggest that the decrease in fluorescence caused by TRH is best explained by displacement of membrane-bound $\mathrm{Ca}^{2+}$, as has been concluded for other secretagogues (28-35).

It has been suggested that stimulation of release of adenohypophyseal hormones may be dependent on extracellular $\mathrm{Ca}^{2+}(36,37)$. This notion was based on observations that anterior pituitary cells in vitro would not respond to secretatogues when incubated in $\mathrm{Ca}^{2+}$. free medium. In most previous studies, however, cells were washed extensively with, or bathed for prolonged periods in, $\mathrm{Ca}^{2+}$-free buffers or buffers containing divalent cation chelators before experimental incubation. We, as well as others (38), have found that exposure of anterior pituitary cells to medium without $\mathrm{Ca}^{2+}$ or with $\mathrm{Ca}^{2+}$ chelators, such as EDTA, caused a marked loss of $\mathrm{Ca}^{2+}$. For example, $\mathrm{GH}_{3}$ cells exposed to BSS with no added $\mathrm{Ca}^{2+}$ or to $0.02 \%$ EDTA for $20 \mathrm{~min}$ contained only 40 (Fig. 5) or $15 \%$ of control ${ }^{45} \mathrm{Ca}^{2+}$, respectively. We propose, therefore, that previous observations of lack of response to TRH were not due to absence of extracellular $\mathrm{Ca}^{2+}$ but were caused instead 
by loss of $\mathrm{Ca}^{2+}$ from a critical cell-associated pool (or pools). In our experiments, in which care was taken to minimize loss of cellular $\mathrm{Ca}^{2+}$, TRH increased ${ }^{45} \mathrm{Ca}^{2+}$ efflux under conditions that completely abolished the increment due to $\mathrm{Ca}^{2+}$ influx usually induced by $\mathrm{K}^{+}$ depolarization.

The relation of the observations reported here to those of electrophysiological studies with adenohypophyseal cells in culture in which the frequency of $\mathrm{Ca}^{2+}$ action potentials was increased by TRH $(9-13)$ is uncertain. Two lines of evidence suggest that these phenomena are separate. First, when $\mathrm{Ca}^{2+}$ is not added to the incubation medium, action potentials in $\mathrm{GH}_{3}$ cells which depend on a $\mathrm{Ca}^{2+}$ mechanism are abolished (10), whereas under these same conditions TRH still causes an increase in ${ }^{45} \mathrm{Ca}^{2+}$ efflux and prolactin release (Figs. 3 and 4). Second, in the presence of verapamil, which is a $\mathrm{Ca}^{2+}$ channel blocker, $\mathrm{Ca}^{2+}$ action potentials are abolished in $\mathrm{GH}_{3}$ (12) and in normal adenohypophyseal cells (13), whereas TRH still enhances ${ }^{45} \mathrm{Ca}^{2+}$ efflux and prolactin release from $\mathrm{GH}_{3}$ cells, although $\mathrm{K}^{+}$-induced efflux and release are inhibited (unpublished observations). It appears, therefore, that the effect of TRH to increase the frequency of action potentials and, perhaps in so doing, to increase $\mathrm{Ca}^{2+}$ influx is not a necessary mechanism for TRH-induced prolactin release.

The data reported here are consistent with the stimulus-secretion coupling hypothesis (4) as regards TRH regulation of prolactin release from anterior pituitary cells. According to this hypothesis, TRH may act to increase free intracellular $\mathrm{Ca}^{2+}$, which then induces secretion of prolactin. The increased ${ }^{45} \mathrm{Ca}^{2+}$ efflux from anterior pituitary cells caused by TRH (Figs. 3 and 4) (5-7) appears to reflect this elevation in free cytosolic $\mathrm{Ca}^{2+}(36)$. We conclude, differently from previous investigators $(2,9-13)$, that the possible increase in free $\mathrm{Ca}^{2+}$ concentration is due, not to net influx of $\mathrm{Ca}^{2+}$ from the medium, which would be associated with an increase in cell-associated $\mathrm{Ca}^{2+}$, but to mobilization of sequestered cell-associated $\mathrm{Ca}^{2+}$ into the cytoplasm. Since TRH interacts with a plasma membrane receptor $(18,39-42)$ and may cause mobilization of $\mathrm{Ca}^{2+}$ from a cellular membrane-associated pool (or pools), this may be analogous to the loss of $\mathrm{Ca}^{2+}$ from the plasma membrane of neutrophils after exposure to secretagogues (43); but subcellular localization of the $\mathrm{Ca}^{2+}$ pool affected by TRH requires further study.

In summary, we have shown that TRH affects cellular $\mathrm{Ca}^{2+}$ metabolism in a manner independent of the concentration of $\mathrm{Ca}^{2+}$ in the incubation medium. We suggest that displacement of $\mathrm{Ca}^{2+}$ from a cellular membrane-associated pool (or pools) may lead to an increase in the intracellular free $\mathrm{Ca}^{2+}$ concentration and to prolactin release. Our studies do not, however, allow any conclusion concerning the role of extracellular $\mathrm{Ca}^{2+}$ in maintaining responsiveness chronically of pituitary cells to TRH, because experiments performed with cells in medium with no added $\mathrm{Ca}^{2+}$ were, by design, only of short duration. They also do not determine whether TRH may increase free intracellular $\mathrm{Ca}^{2+}$ simultaneously by increasing $\mathrm{Ca}^{2+}$ influx during a series of action potentials or whether these separate mechanisms may act synergistically to affect stimulation of prolactin release.

\section{ACKNOWLEDGMENTS}

The authors thank Ms. Patricia Wilson for secretarial assistance.

This work was supported by research grants AM20249, AA04020, and AM25776 from the National Institutes of Health. Dr. Gershengorn and Dr. Hoffstein are recipients of Research Career Development Awards AM0566 and HL00356, respectively, from the National Institutes of Health.

\section{REFERENCES}

1. Vale, W., C. Rivier, and M. Brown. 1977. Regulatory peptides of the hypothalamus. Annu. Rev. Physiol. 39: 473-527.

2. Vale, W., R. Burgus, and R. Guillemin. 1967. Presence of calcium ions as a requisite for the in vitro stimulation of TSH-release by hypothalamic TRF. Experientia (Basel). 10: 853-855.

3. Tashjian, A. H., Jr., M. E. Lomedico, and D. Maina. 1978. Role of calcium in the thyrotropin-releasing hormonestimulated release of prolactin from pituitary cells in culture. Biochem. Biophys. Res. Commun. 81: 789-806.

4. Douglas, W. W. 1968. Stimulus-secretion coupling: the concept and clues from chromaffin and other cells. Br.J. Pharmacol. Chemother. 34: 451-474.

5. Williams, J. A. 1976. Stimulation of ${ }^{45} \mathrm{Ca}^{2+}$ efflux from rat pituitary by luteinizing hormone-releasing hormone and other pituitary stimulants. J. Physiol (Lond.). 260: 105115.

6. Schrey, M. P., B. L. Brown, and R. P. Ekins. 1978. Studies on the role of calcium and cyclic nucleotides in the control of TSH secretion. Mol. Cell. Endocr. 11: 249-264.

7. Vale, W., C. Rivier, M. Brown, L. Chan, N. Ling, and J. Rivier. 1976. Applications of adenohypophyseal cell cultures to neuroendocrine studies. In Hypothalamus and Endocrine Functions. F. Labrie, J. Meites, and G. Pelletier, editors. Plenum Publishing Corp., New York. 397-429.

8. Gershengorn, M. C. 1980. Thyrotropin releasing hormone stimulation of prolactin release. Evidence for a membrane potential-independent, $\mathrm{Ca}^{2+}$-dependent mechanism of action. J. Biol. Chem. 255: 1801-1803.

9. Kidokoro, Y. 1975. Spontaneous calcium action potentials in a clonal pituitary cell line and their relationship to prolactin secretion. Nature (Lond.). 258: 741-742.

10. Biales, B., M. A. Dichter, and A. Tischler. 1977. Sodium and calcium action potential in pituitary cells. Nature (Lond.). 267: 172-173.

11. Ozawa, S., and N. Kimura. 1979. Membrane potential changes caused by thyrotropin-releasing hormone in the clonal $\mathrm{GH}_{3}$ cell and their relationship to secretion of pituitary hormone. Proc. Natl. Acad. Sci. U. S. A. 76: 6017-6020. 
12. Dufy, B., J.-D. Vincent, H. Fleury, P. DePasquier, D. Gourdji, and A. Tixer-Vidal. 1979. Membrane effects of thyrotropin-releasing hormone and estrogen shown by intracellular recording from pituitary cells. Science (Wash. D. C.). 204: 509-511.

13. Taraskevich, P. S., and W. W. Douglas. 1977. Action potentials occur in cells of the normal anterior pituitary gland and are stimulated by the hypophysiotropic peptide thyrotropin-releasing hormone. Proc. Natl. Acad. Sci. U. S. A. 74: 4064-4067.

14. Martin, S., D. H. York, and J. Kraicer. 1973. Alterations in transmembrane potential of adenohypophysial cells in elevated potassium and calcium-free media. Endocrinology. 92: 1084-1088.

15. Caswell, A. H., and J. D. Hutchinson. 1971. Visualization of membrane-bound cations by a fluorescent technique Biochem. Biophys. Res. Commun. 42: 43-49.

16. Hallett, M., A. S. Schneider, and E. Carbone. 1972 Tetracycline fluorescence as calcium-probe for nerve membrane with some model studies using erythrocyte ghosts. J. Membr. Biol. 10: 31-44.

17. Tashjian, A. H., Jr., Y. Yasumura, L. Levine, G. H. Sato, and M. L. Parker. 1968. Establishment of clonal strains of rat pituitary tumor cells that secrete growth hormone. Endocrinology. 82: 342-352.

18. Gershengorn, M. C., B. E. Marcus-Samuels, and E. Geras. 1979. Estrogens increase the number of thyrotropinreleasing hormone receptors on mammotropic cells in culture. Endocrinology. 105: 171-176.

19. Bancroft, F. C. 1973. Measurement of growth hormone synthesis by rat pituitary cells in culture. Endocrinology. 92: 1014-1021.

20. Scarpa, A., F. J. Brinley, T. Tiffert, and G. R. Dubyak. 1978. Metallochromic indicators of ionized calcium. Ann. N. Y. Acad. Sci. 307: 86-112.

21. Carafoli, E., and M. Crompton. 1978. The regulation of intracellular calcium. Curr. Top. Membr. Transp. 10: 151-216.

22. Lowry, P. J., and C. McMartin. 1974. Measurement of the dynamics of stimulation and inhibition of steroidogenesis in isolated rat adrenal cells by using column perifusion. Biochem. J. 142: 287-294.

23. Finkelstein, M. C., and E. A. Adelberg. 1977. Neutral amino acid transport in an established mouse lymphocytic cell line. J. Biol. Chem. 252: 7101-7108.

24. Matthews, E. K., O. H. Petersen, and J. A. Williams. 1973. Pancreatic acinar cells: acetylcholine-induced membrane depolarization, calcium efflux and amylase release. $J$. Physiol. (Lond.). 234: 689-701.

25. Douglas, W. W. 1978. Stimulus-secretion coupling: variations on the theme of calcium-activated exocytosis involving cellular and extracellular sources of calcium. Ciba Found. Symp. 54: 61-90.

26. Milligan, J. V., and J. Kraicer. $1971 .{ }^{45} \mathrm{Ca}$ uptake during the in vitro release of hormones from the rat adenohypophysis. Endocrinology. 89: 766-773.

27. Eto, S., J. McMillin Wood, M. Hutchins, and N. Fleischer 1974. Pituitary ${ }^{45} \mathrm{Ca}^{++}$uptake and release of $A C T H$ GH, and TSH: effect of verapamil. Am. J. Physiol. 226: $1315-1320$
28. Caswell, A. H. 1972. The migration of divalent cations in mitochondria visualized by a fluorescent chelate probe. J. Membr. Biol. 7: 345-364.

29. Luthra, R., and M. S. Olaon. 1976. Studies of mitochondrial calcium movements using chlorotetracycline. Biochim. Biophys. Acta. 440: 744-758.

30. Taljedal, I.-B. 1978. Chlorotetracycline as a fluorescent $\mathrm{Ca}^{2+}$ probe in pancreatic islet cells: methodological aspects and effects of alloxan, sugars, methylxanthines, and $\mathrm{Mg}^{2+}$. J. Cell Biol. 76: 652-674.

31. Chandler, D. E., and J. A. Williams. 1977. Fluorescent probe detects redistribution of cell calcium during stimulus-secretion coupling. Nature (Lond.). 268: 659-660.

32. Chandler, D. E., and J. A. Williams. 1978. Intracellular divalent cation release in pancreatic acinar cells during stimulus-secretion coupling. I. Use of chlorotetracycline as fluorescent probe. J. Cell Biol. 76: 371-385.

33. Chandler, D. E., and J. A. Williams. 1978. Intracellular divalent cation release in pancreatic acinar cells during stimulus-secretion coupling. II. Subcellular localization of the fluorescent probe chlorotetracycline. J. Cell Biol. 76: 386-399.

34. Naccache, P. H., H. J. Showell, E. L. Becker, and R. I. Sa'afi. 1979. Involvement of membrane calcium in the response of rabbit neutrophils to chemotactic factors as evidenced by the fluorescence of chlorotetracycline. $J$. Cell Biol. 83: 179-186.

35. Caswell, A. H., and S. Warren. 1972. Observations on calcium uptake by isolated sarcoplasmic reticulum employing a fluorescent chelate probe. Biochem. Biophys. Res. Commun. 46: 1757-1763.

36. Rasmussen, H., and D. B. P. Goodman. 1977. Relationships between calcium and cyclic nucleotides in cell activation. Physiol. Rev. 57: 421-509.

37. Trifaro, J. M. 1977. Common mechanisms of hormone secretion. Annu. Rev. Pharmacol. Toxicol. 17: 27-47.

38. Milligan, J. V., and J. Kraicer. 1974. Physical characteristics of the $\mathrm{Ca}^{++}$compartments associated with in vitro ACTH release. Endocrinology. 94: 435-443.

39. Grant, G., W. Vale, and R. Guillemin. 1972. Interaction of thyrotropin-releasing factor with membrane receptors of pituitary cells. Biochem. Biophys. Res. Commun. 46: 28-34.

40. Labrie, F., N. Barden, G. Poirier, and A. DeLean. 1972. Binding of thyrotropin-releasing hormone to plasma membranes of bovine anterior pituitary gland. Proc. Natl. Acad. Sci. U. S. A. 69: 283-287.

41. Hinkle, P. M., and A. H. Tashjian, Jr. 1973. Receptors for thyrotropin-releasing hormone in prolactin producing rat pituitary cells in culture. J. Biol. Chem. 248: $6180-6186$

42. Gershengorn, M. C. 1978. Bihormonal regulation of the thyrotropin-releasing hormone receptor in mouse pituitary thyrotropic tumor cells in culture. J. Clin. Invest. 62: $937-943$.

43. Hoffstein, S. T. 1979. Ultrastructural demonstration of calcium loss from local regions of the plasma membrane of surface-stimulated human granulocytes. J. Immunol. 123: 1395-1402. 